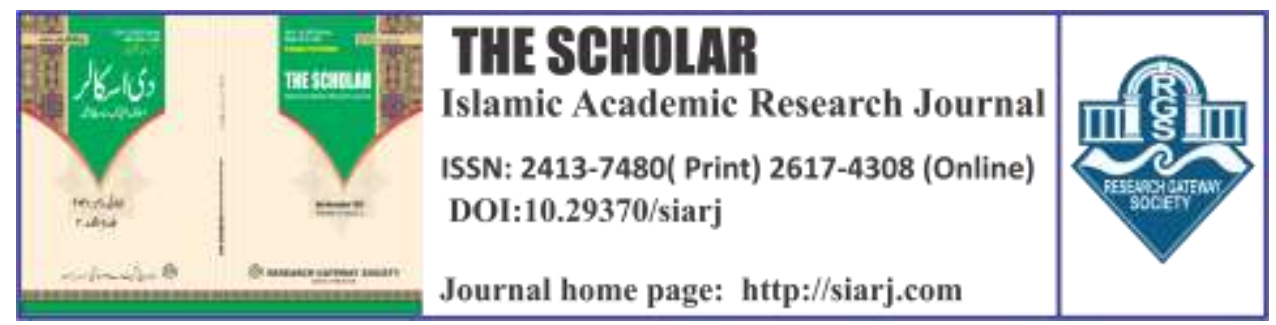

THE QURANIC CONCEPT OF GUIDANCE AND IGNORANCE, A CRITICAL STUDY

\section{Muhammad Ayaz}

Patron \& Executive Editor of International Research Journal on Islamic Studies, Bahawalpur, Punjab, Pakistan

Email: ayaz.te.bwp@gmail.com

ORCID ID:

https://orcid.org/0000-0002-3817-7675

\section{Muhammad Ameen Saeedi} Ph.D. Scholar, Department of Islamic Studies, The Islamia University of Bahawalpur, Pakistan Email: hmas193@gmail.com

\section{ORCID ID:}

https://orcid.org/0000-0002-7936-5701

To cite this article:

Ayaz Muhammad, Muhammad Ameen Saeedi. "THE QURANIC CONCEPT OF GUIDANCE AND IGNORANCE, A CRITICAL STUDY" The Scholar-Islamic Academic Research Journal 6, No. 2 (December 23, 2020): 30-47.

To link to this article: https://doi.org/10.29370/siarj/issue11ar2

\begin{tabular}{|c|c|}
\hline Journal & $\begin{array}{l}\text { The Scholar Islamic Academic Research Journal } \\
\text { Vol. 6, No. } 2 \text { ||July-December } 2020 \text { || P. 30-47 } \\
\text { Research Gateway Society }\end{array}$ \\
\hline Publisher & Research Gateway Society \\
\hline DOI: & 10.29370/siari/issue11ar2 \\
\hline$\overline{\text { URL: }}$ & https://doi.org/10.29370/siarj/issue11ar2 \\
\hline License: & Copyright c 2017 NC-SA 4.0 \\
\hline Journal homepage & www.siari.com \\
\hline Published online: & $2020-12-23$ \\
\hline
\end{tabular}
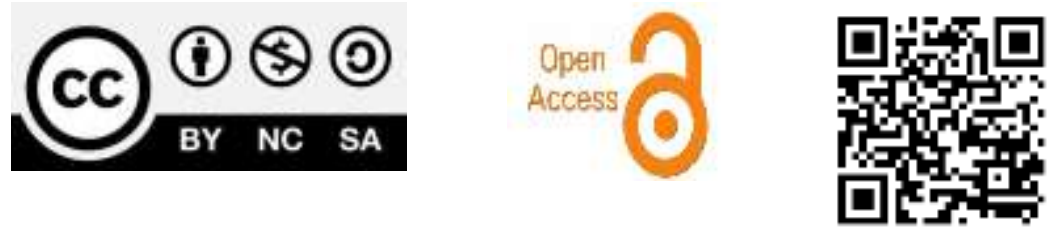
THE SCHOLAR (July- December 2020)

\title{
THE QURANIC CONCEPT OF GUIDANCE AND IGNORANCE, A CRITICAL STUDY
}

\author{
Muhammad Ayaz, Muhammad Ameen Saeedi
}

\begin{abstract}
:
The study is chosen to dispel doubts about guidance and ignorance in the minds of Muslims and to light the candle of awareness. Because in the present era, people with a secular mindset are confusing the innocent people in this debate and inviting them to abhor religion. In this research, an effort has been made to convey the truth to the people in the light of the Holy Quran and the Sunnah of the Prophet Muhammad (PBUH). There is no doubt that Allah is supreme. He does what He wants. He has the power to create results without possibilities. He is free from all types of reasons and causes of any work. This materialistic universe moves under the rules and regulations farmed by Allah. Allah does everything with His knowledge, power, and reason. But there are some rules and codes to understand this issue, which has been discussed below in detail.
\end{abstract}

KEYWORDS: Guidance, Ignorance, Blessing, Bestow, Power

\section{INTRODUCTION}

Allah is running this universe with some rules and codes. As if a man walks then only he can cover the miles. If he drinks water only then he can quench the thirst. The concept of guidance and ignorance is described in detail in the Holy Quran. The concept of guidance and ignorance can be understood well through the following interpretations. Before going to the interpretations the hypothesis and research methodology are being discussed for a better understanding of the topic. 


\section{HYPOTHESIS}

I. The concept of guidance and ignorance is best described in the Holy Quran.

II. Allah does not impose guidance and ignorance by force.

III. The guidance is provided on demand.

\section{RESEARCH METHODOLOGY}

The following principles have been kept in mind during the research.

I. During the research, the narrative and logical style have been adopted.

II. Examples of everyday life that are easy to understand for the benefit of researchers are mentioned.

III. Translation of Quranic verses and Hadiths has been arranged.

IV. References are given in the footnote by using Zotero Software.

\section{GUIDANCE IS NOT IMPOSED}

The base of a human trial in his activities is the power that is bestowed by Allah. Allah doesn't impose any guidance on humans. He doesn't like controlled worship. He likes worship by choice. He never bound any human instead of His power and guidance. But He let all humans say yes or no to His commandments.

It is said in the Holy Quran:

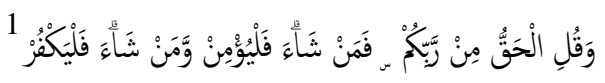

"And say thou: the truth is from your Lord; let him therefore who will, believe, and let him who will, disbelieve."

\footnotetext{
1 "Al-Quran," in Al-Kahf, v. 29.
} 
It is said on another place:

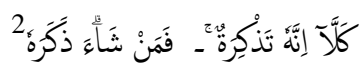

"Never! Indeed, this is a Reminder. So, whoever so wishes may take advice from it." It is also said:

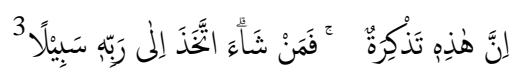

"Indeed, this is a reminder; so let anyone who so wishes, adopt a way to his Lord."

It is clear through these verses that God has cleared in Holy Quran till the end that humans are not bound to accept it rather humans are given choice in this regard to accepting it or not. Humans will get rewards or punishment in both cases. If Allah bounds humans and He took the power then every human has to accept the commandment of the Holy Quran necessarily. In the Holy Quran, it is cleared in different places. At one place it is written that:

$$
4
$$

"Had your Lord willed, all those on earth would have believed altogether.

Would you, then, compel people, so that they become believers?"

This means if Allah wants to get the power of choice back from people and wants to make them pious then every person would be a piousman. But Allah doesn't want to impose anything by force. Instead, Allah wants everything by choice by people. In another place, it is said that:

$$
5
$$

\footnotetext{
2 "Al-Quran," in Al-Mudassir, v. 54-55.

3 "Al-Quran," in Ad-Adhr, v. 29.

4 "Al-Quran," in Younus, v. 99.

5 "Al-Quran," in Hud, v. 118.
} 
"Had your Lord willed, He would have made all the people a single community. But, they will continue in their differences."

In another place it is described for orientalists:

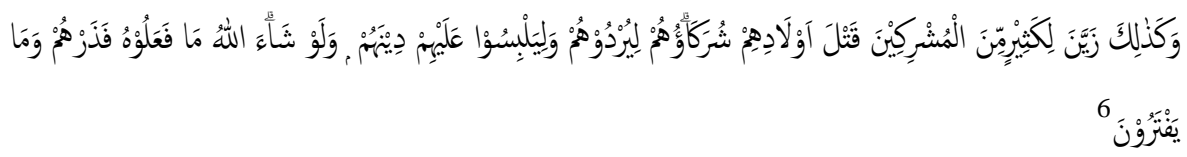

"Similarly, their associate-gods have made the killing of their children seem fair to many mushriks (idolators), so that they may ruin them and may confuse their faith for them. Had Allah so willed, they would not have done that. So, leave them alone with what they fabricate."

This means if Allah wants to stop them by force $\mathrm{He}$ can but $\mathrm{He}$ doesn't do so by force instead that He demands human guidance. He clears the reality or truth but He didn't force humans to accept it. It is said:

$$
7
$$

"There is no compulsion in Faith. The correct way has become distinct from the erroneous."

This is the only aspect of Allah's rule of guidance and ignorance due to which a human thinks by not understanding that when Allah is the eternal absolute and $\mathrm{He}$ is happy with pious people then why doesn't bestow guidance to them. So this is also described in the Holy Quran regarding the way of thinking of the ignorant.

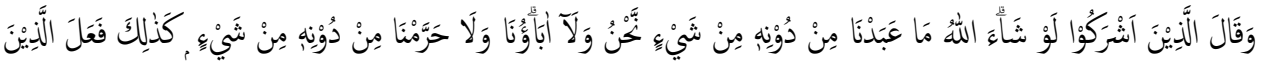

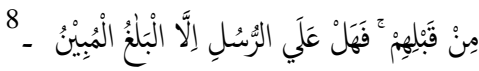

\footnotetext{
6 "Al-Quran," in Al-An'am, v. 137.

7 "Al-Quran," in Al-Baqarah, v. 256.

8 "Al-Quran," in Al-Nahl, v. 35.
} 
"The polytheists said, If Allah had so willed, we would have not worshipped anything other than Him - neither we nor our forefathers - nor would we have made anything unlawful without (a command from) Him. Similar was the reaction of those who were before them. Therefore, messengers" obligation is no more than to convey the message clearly." It is also said in another place keeping in view their thinking:

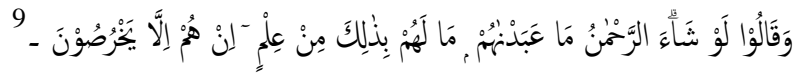
"They say, Had the Rahman so willed, we would not have worshipped them. They have no knowledge of that. They do nothing but make conjectures."

It is clear in this verse that Allah is eternal absolute but He doesn't impose guidance by force. So when people say that God has every power to stop me from ignorance then why doesn't stop me. It is the only effort to blame God and misunderstanding which is the result of less knowledge. Regarding guidance, it is the first step of Allah's rule that He has cleared everything regarding guidance and ignorance. He has provided the complete reasons to accept it but the choice is given to humans either they accept it or not. It is not imposed on a human because Allah doesn't like guidance by force. He wants guidance by choice. Allah doesn't impose guidance to anyone but $\mathrm{He}$ only bestows to them who wants it. It is described at various places in the Holy Quran.

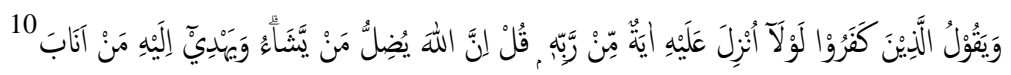

\footnotetext{
9 "Al-Quran," in Az-Zukhruf, v. 20.

10 "Al-Quran," in $A r-R a$ 'd, v. 27.
} 


\section{The Quranic Concept of Guidance and Ignorance, a Critical Study}

"The disbelievers say, why is it that no sign (of their choice) has been sent down to him from his Lord? Say, Allah lets go astray whom He wills and gives guidance to those who turn to Him."

It is said in another place:

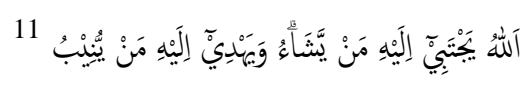

"Allah chooses (and pulls) toward Himself anyone He wills, and guides to Himself anyone who turns to Him (to seek guidance)."

This means the ways of guidance is not open to everyone but only people who want to walk on such roads Allah open His ways to them.

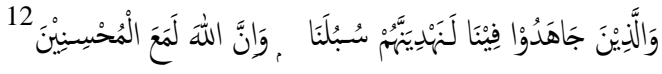

"As for those who strive in Our way, We will certainly take them onto Our paths, and indeed Allah is with those who are good in deeds."

Holy Quran is a book of guidance only for those who implement the guidance of Allah. But only those who want to get guidance from this book can only take it. It is said in the Holy Quran:

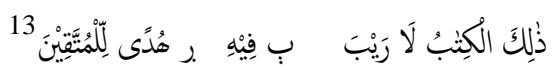

"This Book has no doubt in it - a guidance for the God-fearing,"

It is meant that only those who demand piety and guidance from Allah can only get from this book. Imam Siyoti (R.A) said in this regard:

$$
\text { الصائرين الى لتقوى بامتنال الاوامر و اجتناب المعاصى } 14
$$

"Those that tend towards piety by adhering to commands and avoiding things prohibited."

\footnotetext{
11 "Al-Quran," in Ash-Shura, v. 13.

12 "Al-Quran," in Al-'Ankabut, v. 69.

13 "Al-Quran," in Al-Baqarah, v. 2.

${ }^{14}$ Jalal ad-Din al-Mahalli and Jalal ad-Din as-Suyuti, Tafsir Al-Jalalayn, vol. 1 (Karachi: Qasim Publications, n.d.), 41.
} 


\section{The Quranic Concept of Guidance and Ignorance, a Critical Study}

It is said by Imam Al-Sawi that righteousness can refer to two things.

$$
\text { الاول المتقين فى علم الله او من يوول الى كونهم متقين } 15
$$

It is clear that the Holy Quran is a book of guidance for the whole of humanity but only those who demand guidance can get it. The power of logic is an undeniable reality. But if reality is not demanded then a person becomes helpless before logic but he remains to deprive of guidance because those who demand guidance with the purity of heart can only get it. And on the other hand a stubborn and clumsy man cannot get guidance from God.

The best example of this fact can be described with the dialogue of Prophet Ibrahim (A.S) and Nimrod.

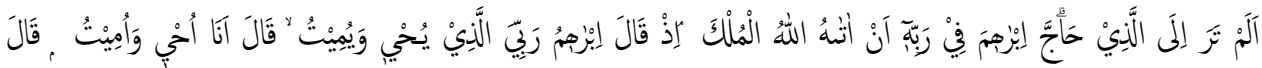

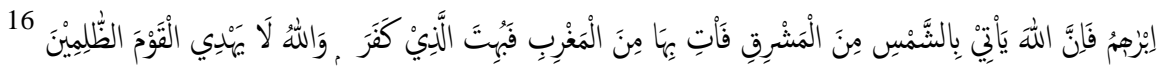

"Do you not know the one who argued with Ibrahim about his Lord, because Allah had given him kingship? When Ibrahim said: My Lord is the One Who gives life and brings death, he said: I give life and I bring death. Said Ibrahim: Allah brings the sun out from the East; now, you bring it out from the West. Here, baffled was the one who disbelieved, and Allah does not bring the wrongdoers to the right path."

It was required that when Namrood failed in his logic he must be convinced by Prophet Ibrahim (A.S) but because he didn't require guidance by heart and he remained fixed on false. At this point, Allah cleared His code of guidance in clear words that He does not bestow guidance to cruel. At this point, cruel people are meant by those people

\footnotetext{
15 Jalal ad-Din al-Mahalli and as-Suyuti, 1:42.

16 "Al-Quran," in Al-Baqarah, v. 258.
} 


\section{The Quranic Concept of Guidance and Ignorance, a Critical Study}

who do not demand guidance and do not leave stubbornness even if things are clear to them. The rule of God is that the gates of guidance are closed on such people and guidance is given to those who want it.

Allah has supreme power over everything. He blessed people with His hands. To whom He wants He gives. But He only gives humans what they demand or required from Him. Those who demand limited can get only a few. And those who demand unlimited they get accordingly.

Allah said in the Holy Quran:

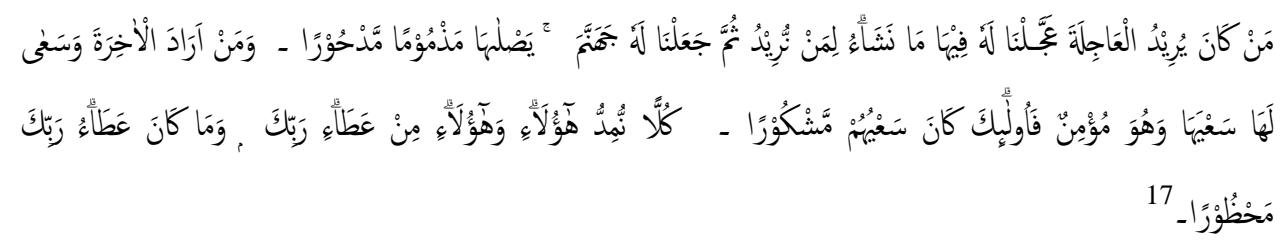

"Whoever opts for the immediate (benefits from) life herein, We give him, right here in this life, as much as We will, to whomever We intend. Then We assign Jahannam for him where he shall enter condemned, discarded. And whoever opts for the Hereafter and makes efforts for it as due, while he is a believer, then, the effort of such people is appreciated! To all of them - both these and those - We extend the grants of your Lord. And the grant of your Lord is not barred (for anyone)."

The way every person takes according to his behavior the same is the case with guidance. Those who stick with less knowledge and what they have got nothing. The person who resolves his doubts in the way of guidance that person is cleared from all doubts. And those who keep saying:

$$
18
$$

17 “Al-Quran," in Al-Isra, v. 18-20. 


\section{The Quranic Concept of Guidance and Ignorance, a Critical Study}

"My Lord, improve me in knowledge."

They after getting an extreme rank of knowledge God even keeps them bestowing.

The results and fruits of all behavior and indifferences are described in detail in the Holy Quran. Jews on which humiliation and disgrace imposed due to their falls practices and they were considered sinful due to the disregard of Holy Quran and when reality came before them with pump and show they simply considered their ignorance enough and remained fixed due to this behavior and selfishness they were deprived of guidance. Allah said:

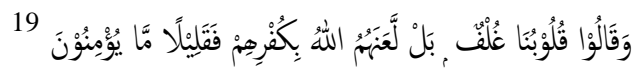

"And they said, Our hearts are veiled. Rather, Allah has cast damnation upon them for their disbelief. So, they believe just in very little things."

In this verse, the practicalities of Jews are described that they didn't give importance to the invitation of Islam and said that our belief is firm and nothing can enter in our heart. Because they didn't demand reality that is why this behavior was made a cause of their ignorance and they were cursed. A person is described in the Holy Quran who passed by a ruined area so he thought how would God will create this ruined tertiary alive? He was not the deniers of the power of Allah but he simply wanted to clear the doubts. Allah imposed death upon him and then he has put alive and he was asked how long you stayed here? He replies a day or some part of the day. Allah said no you stayed here for a hundred years. See your eatables they are not spoiled and look at your donkey. So that we could make you an example for people. Look at the bones that how we

\footnotetext{
18 "Al-Quran," in Ta-Ha, v. 114.

19 "Al-Quran," in Al-Baqarah, v. 88.
} 


\section{The Quranic Concept of Guidance and Ignorance, a Critical Study}

make a structure and then add flesh and then by the order of God the structure of donkey made and he became alive. Allah said in the Holy Quran:

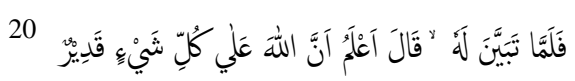

"So, when it was clear to him, he said: I know that Allah is Powerful over everything."

It was an example of that person who wanted to clear his doubts. Allah removes his doubts and strengthened his beliefs. Any person who strengthens his belief in God is given by Him. Prophet Ibrahim (A.S) said O my Lord show me the way how you will alive the dead then Allah said don't you believe? Prophet Ibrahim (A.S) said yes I believe but I just want to satisfy my heart.

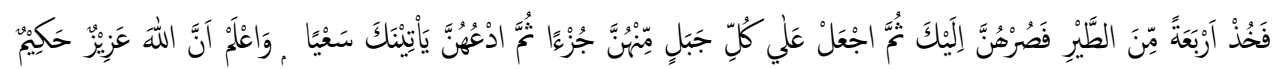

"Then take four birds and tame them to your call, then put on every mountain a part from them, then give them a call, and they shall come to you rushing, and know that Allah is Mighty Wise."

\footnotetext{
20 "Al-Quran," in Al-Baqarah, v. 259.
}

21 "Al-Quran," in Al-Baqarah, v. 260. 
It has become clear that Prophet Ibrahim (A.S) was given much as he demanded through a question. The way of guidance has no limit same is the case with demand as well. Perhaps this is the reason that every person is asked to request guidance (Hidayah) again and again in prayers. A person who is in pursuit of a forthcoming destination is bestowed accordingly. In the same way as the ranks of Prophet Muhammad (PBUH) got higher and higher. In this regard it is said in the Holy Quran:

$$
22
$$

"Surely the Hereafter is much better for you than the present life."

Even so, Prophet Muhammad (PBUH) used to pray to Allah with these words.

$$
23 \text { قُلْ رََبِّ زِدِنِنِ عِلْمًا }
$$

“And say, My Lord, improve me in knowledge."

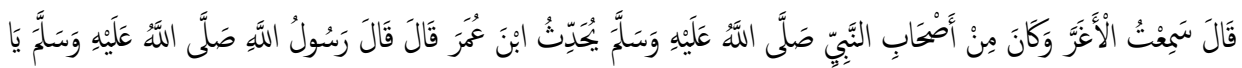

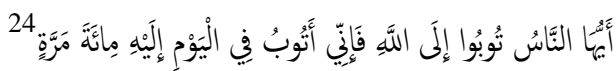

"Al-Agharr al-Muzani who was from amongst the Companions of Allah's Apostle (PBUH) reported that Ibn 'Umar stated to him that Allah's Messenger (PBUH) said: O people, seek repentance from Allah. Verily, I seek repentance from Him a hundred times a day."

This can be understood through these realities that guidance is as per request, every person must seek the guidance of high and higher ranks

\footnotetext{
22 "Al-Quran," in Ad-Dhuha, v. 4.

23 "Al-Quran," in Ta-Ha, v. 114.

${ }^{24}$ ibn al-Hajjaj Abu al-Hasan al-Qushairi Muslim, "Sahih Muslim," vol. 3, 7 vols. (Beirut, Lebanon: Maktaba Darussalam, n.d.) 2702.
} 
The Scholar Islamic Academic Research Journal

Vol. 6, No. 2 || July -December 2020 || P. 30-47

https://doi.org/10.29370/siarj/issue11ar2

and he must not stop. Every person who will request high will get enough and those who stop seeking are deprived of everything.

\section{SINS DEPRIVE OF GUIDANCE OF ALLAH}

This point has been clearly described in the Holy Quran in the code of guidance and ignorance that sometimes the humans are kept deprived of the guidance due to sin. The main cause of human ignorance is sin. Those humans who avoid sin can be given the light of guidance. Keeping in view the above discussion it has been said in the Holy Quran:

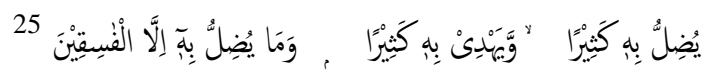

"He lets many go astray, and by this, He makes many find guidance. But He does not let anyone go astray thereby except those who are sinful."

This means the disobedience and ignorance of the person became the main reason for this astray. If a person would be stub-run, egoistic, hard at heart, and opportunist then these things will become a hindrance in his way of guidance. It is said in the Holy Quran:

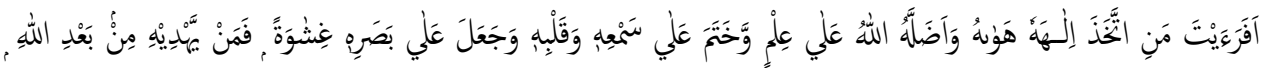

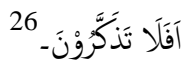

"So, have you seen him who has taken his desires as his god, and Allah has let him go astray, despite having knowledge, and has sealed his ear and his heart, and put a cover on his eye? Now, who will guide him after Allah? Still, do you not take a lesson?"

This is becoming clear through this verse that a person who is blessed by the power of knowledge but instead of in-lighting his hearth he

\footnotetext{
25 "Al-Quran," in Al-Baqarah, v. 26.

26 "Al-Quran," in Al-Jathiyah, v. 23.
} 
starts running behind his wishes and due to which he was completely deprived of Hidayat. The main reason for the ignorance of Jews is their sins and their insurrection.

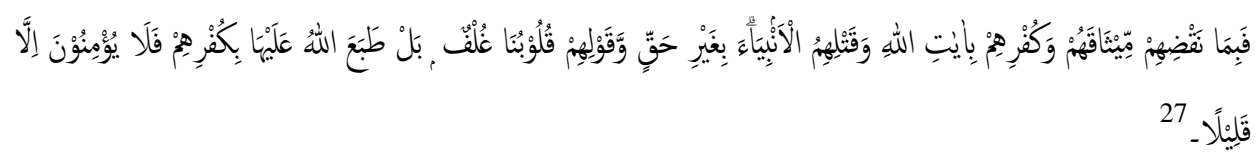

"So, (they met their fate) for breaking their pledge, and for their disbelief in the verses of Allah, and their slaying of the prophets unjustly, and for their saying, Our hearts are sealed - rather, Allah has set a seal over them for their disbelief, so they do not believe but a little."

This is becoming clear through this verse that the reason for Jews ignorance is due to the breaking of promises, denial of the verses of the Holy Quran and to commit the sin of murdering the Prophets and above all, they kept on saying that nothing can enter in our hearths they are sealed. Allah says that their hearts are not sealed rather they are stamped by Allah and they are deprived of guidance.

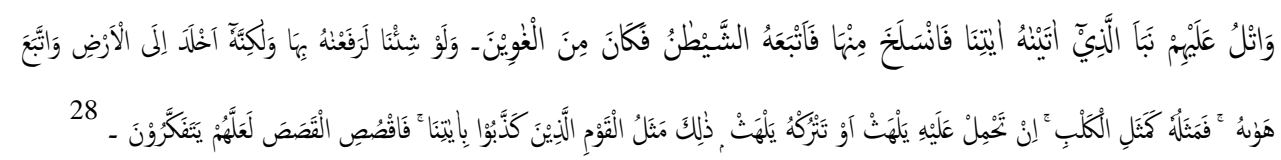
"Recite to them the story of the one whom We gave Our verses, then he wriggled out from them, so Satan pursued him and he became one of the perverted. If We are so willed, We would have elevated him thereby; but he clung to the earth and followed his desires. So, his example is like the example of a dog, if you attack him, he pants with his tongue protruding, and if you leave him alone he still pants with his tongue protruding. That

\footnotetext{
27 "Al-Quran," in An-Nisa', v. 155.

28 "Al-Quran," in Al-A'raf, v. 175-176.
} 
is the example of those who rejected Our signs. So, relate the chronicles, so that they may ponder."

These secret verses describe the reason for that ignorant person to whom God has blessed with knowledge but he completely disgraced this knowledge and as a result, Devil (Satan) imposed on him and he became ignorant. When he kept following his wishes then God didn't impose guidance on him. He fell from the higher rank and kept falling then he became just like a dog who shivers in all conditions greed and curse imposed on him as much as he is satiated even then he sniffs the ground in search of anything to eat. The same is the case with the person who is bestowed with the higher rank of knowledge but his desires made him ignorant and he forgot all moral and social boundaries and values and remained busy in materialism.

"These Ayah were revealed about the story of Bal'am son of Ba 'ura'. It was also said that the meaning here is a parable of this man -- and his like -- concerning their misguidance, persisting the wrong path and not being able to benefit from faith or comprehend what they are being called to. So his example is that of a dog which pants whether it was driven away or left alone. The person described here does not benefit from the advice or the call to faith, just as if the advice and call never occurred." 29

The rule of guidance and ignorant is very clear and undeniable from Holy Quran that only virtues act of humans only opens the door of guidance and sins pushes humans towards the ignorance following the commandants of God only keeps human on the right path and running

\footnotetext{
${ }^{29}$ Abu Al-Fida' Isma il bin 'Umar bin Kathir 'Imad Ad-Din, "Tafsir Ibn Kathir," vol. 4 (Beirut, Lebanon: Maktaba Darussalam, n.d.), 255.
} 
towards the wishes and self-indults a person into ignorant. Which he never thought about it. Those who themselves were ignorant and kept the Ummas into the darkness of ignorance their life was also empty from the light of piety. Their self and ego put them in darkness and they were also accused to keep others in darkness.

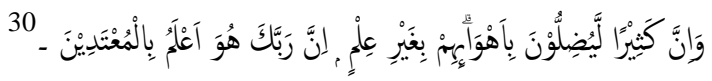

"Surely, there are many who misguide people on the basis of their desires without having knowledge. Surely, your Lord is the best knower of those who cross the limits."

It is becoming clear from the explanation of the Quran that the impractical tie and following the self is the big source of ignorance. If heart and enlightens with the light of piety even then it could not hearth from the right with poor logic but if the light of piety extinguished even then the strong reasons couldn't keep it away from ignorance.

\section{GUIDANCE AND BLESSING OF ALLAH}

It is said by Imam Ghazali that human is like labor who's the reward of livelihood is given in mother womb. And he couldn't pay back in his whole life. It is not necessary for God to whom He has given, it is due to His blessing. It is correct that God is running this universe under a rule and a code of conduct but $\mathrm{He}$ is eternal absolute, but $\mathrm{He}$ is not bound to that rule. The rule of guidance and ignorance is fixed but those who get it must not be understood or assume that they got it through their efforts but they must believe that these efforts of mine are the result of God's blessing.

\footnotetext{
30 “Al-Quran," in Al-An'am, v. 119.
} 


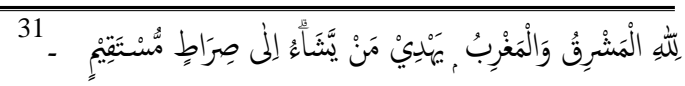

"Allah belong the East and the West. He guides whom He wills to a straight path."

Here guidance has been depended on the will of God. It can be said in its logic that He awarded guidance as per His code of guidance. It is true at its place that same how He awarded guidance by His mercy. It is said in the Holy Quran:

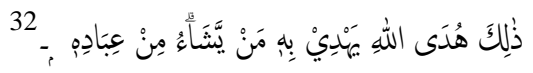

"That is Allah's guidance. He guides with it whomsoever He wills from among His servants."

It is also said in another place.

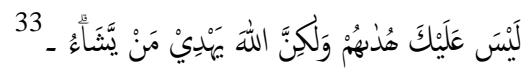

"It is not for you to put them on the right path. Rather, Allah puts on the right path whom He wills."

Faith requires that whoever got the guidance must believe that God has given him through His mercy. When Hazrat Abdullah undlasi gone through the toughest trial of acceptance of Christianity and then God has bestowed guidance upon him, then he was questioned about this situation that what the matter was. He said I was passing through the area of idol worshipers then in view came to my heart how silly people are who worship lifeless idols and then I got the reality and only worship God. I just thought of and I listened to a voice from invisible that if you are on truth it's your wisdom or due to my mercy? And then everything was

\footnotetext{
31 "Al-Quran," in Al-Baqarah, v. 142.

32 "Al-Quran," in Al-An'am, v. 88.

33 “Al-Quran," in Al-Baqarah, v. 272.
} 
The Scholar Islamic Academic Research Journal

Vol. 6, No. 2 || July -December 2020 || P. 30-47

https://doi.org/10.29370/siarj/issue11ar2

taken away. A man must never think that whatever guidance he gets due to his intelligence and hard work rater he must give the matter in the Hands of Allah. This is the requirement of respect and the voice of faith. It is said in the Holy Quran that:

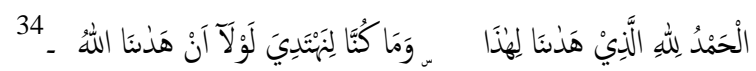

"All praise is to Allah who has guided us to this. We would not have been able to find the way, had Allah not guided us."

Prophets (A.S) said:

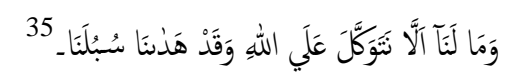

What is wrong with us that we should not put our trust in Allah when He has guided us to our paths?

It is stated clearly in the Quran that God can give guidance merely due to His mercy to those who don't even demand. Means, He not only gives guidance to those who search for it but also given to those who even do not search for it. But He only astray to those who are fixed with their wrong path with practice.

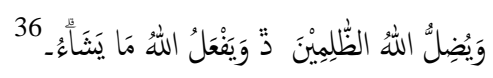

"Allah lets the unjust go astray; and Allah does what He wills."

It is clear with it that ignorance is only imposed on those who think he deserves it. While the guidance is given to those who deserve guidance. So it is the requirement of faith that everyone must understand that guidance is only due to the mercy of God.

\footnotetext{
34 "Al-Quran," in Al-A'raf, v. 43.

35 "Al-Quran," in Ibrahim, v. 12.

36 "Al-Quran," in Ibrahim, v. 27.
} 
The Scholar Islamic Academic Research Journal

Vol. 6, No. 2 || July -December 2020 || P. 30-47

https://doi.org/10.29370/siarj/issue11ar2

\section{CONCLUSION}

The gist of this discussion is clear due to these points.

1. Allah doesn't impose guidance even then $\mathrm{He}$ is eternal absolute.

2. Guidance is given to those who demand it under the rule of guidance and ignorance.

3. Guidance is as per demand.

4. Sins are the hurdles in the way of guidance.

5. God bestows guidance due to His mercy even without any human effort but He artery those who deserve this.

\section{(1)(8)}

BY NC SA This work is licensed under a Creative Commons

Attribution-NonCommercial-ShareAlike 4.0 International (CC BY-NC-SA 4.0) 